\title{
Headmaster Management to Improve Teacher Performance in SingKaWANG SENIOR High SCHOOLS
}

\author{
Syahrudin \\ Universitas Terbuka, Pontianak, Indonesia \\ E-mail: syah13februari@gmail.com
}

\begin{abstract}
The progress of education of a school as an educational institution is influenced by the role of the principal as an education manager. It is very much determined by the principal's ability to manage human resources from the planning to evaluation aspects. This study aims to reveal the management of school principals to improve the performance of teachers in Singkawang State High School 3 with a focus on 1) The description of the planning of quality improvement programs for teacher performance by the headmaster of State High School 3 Singkawang, 2) The implementation of programs to improve the quality of teacher performance by principals in State High Schools 3 Singkawang, 3) Program evaluation activities to improve the quality of teacher performance carried out by school principals in SMA 3 Singkawang. The research method used is descriptive research with a qualitative approach. Data collected by in-depth interviews, participant observation, documentation, and analyzed through data reduction, data presentation, conclusions or verification. Data reliability testing is done by extending the period of observation, and triangulation and member checking. The results of the study conclude 1) planning of quality improvement programs for teacher performance is carried out with reference to the vision and mission and school work plans. 2) implementation of improving the quality of teacher performance is carried out by holding a program of continuous professional development in the form of technical guidance (BIMTEK) learning development activities, In House Training (IHT) and workshops aimed at improving teacher competence and quality of learning, 3) Evaluation of teacher performance is carried out by carrying out activities academic supervision of teachers and managerial supervision of administration. Based on the results of the study suggested the following things: 1) planning for improving the quality of teacher performance, especially in school work plans need to be improved in a continuous professional improvement program. 2) The form of carrying out continuous professional improvement activities should be adjusted to what is required by the teacher. 3) Evaluation activities should be carried out consistently to improve teacher quality.
\end{abstract}

Keywords: Management; Principal; Teacher Performance

\section{INTRODUCTION}

An organization is formed to achieve common goals, but to achieve organizational goals effectively requires proper and correct management. Whether we realize it or not, organizational culture is something real and has a strong influence. Because understanding the foundation of an influential culture is very important because a strong culture produces high performance and gives a competitive advantage to the organization. Like the opinion of Robert Waterman, Jr. in Supratikno (2006: 39) states:

"The third set of values is regarding the activities of the organization. Organizations must develop values and norms that motivate their employees to do their best. These values develop from a belief that productivity is achieved through human resources, and because of that, respect for individuals is the primary way the organization creates a culture that is suitable for productive behavior".

Thus it is seen that productive behavior as part of a performance is built from positive values and culture that are built by the organization and consistently implemented by members for maximum productivity (Sulaksono, 2015). Performance behavior as part of organizational culture certainly is not formed by itself. There needs to be a planned and systematic effort made by the organization, one of them through a pattern of performance management. Performance management is management about creating relationships and ensuring effective communication. "Performance management focuses on what is needed by organizations, managers, and workers to succeed" (Wibowo, 2011: 7). Human resources are an essential asset of educational institutions because of their role as subjects of implementing policies and operational activities of educational institutions. 
For educational institutions to continue to exist, they must be brave in facing challenges and their implications, namely facing changes and adjusting work demands. Resources owned by educational institutions such as capital, methods and machines cannot provide optimal results if they are not supported by human resources (HR) that have optimal performance, both by the principal, teachers (educators), and education staff. Excellent performance is expected to improve the quality of education in schools.

Efforts to improve the quality of education, both from the community and the government, continue to be carried out. When viewed from a micro perspective, enhancing the quality of education is mostly determined by the operationalization of management at the level of educational institutions. The main role that does this is the leadership of the institution itself by involving all existing human resources. Principals are required to be professional and to master their work well, to exceed other personal averages, and to have high moral commitment.

The progress of education of a school as an educational institution is influenced by the role of the principal as an education manager (Mulyasa, 2013). It is very much determined by the principal's ability to manage human resources from the planning to evaluation aspects. Thus the effectiveness of the implementation of the tasks and implementation of education in schools is influenced by managerial ability. It was confirmed by Danim (2010: 30) stating: "In every work environment, an effective leader is important to demonstrate healthy and productive survival in the workplace". It means that management is supported by the excellent leadership of the school principal and the performance of good educators and educators as well as adequate infrastructure so that quality education will be carried out. Management that is based on democratic principles to improve the quality of education starting from the planning process to the evaluation focuses on improving the quality of the performance of human resources in addition to other resources including in high schools.

SMA Negeri 3 Singkawang is a government-owned educational institution and has the role of educating, teaching, and producing high school graduates who are prepared to continue to Higher Education. Human resources in SMA Negeri 3 Singkawang include the school principal, deputy head three people. Has 26 permanent teaching staff (PNS) and two permanent teaching staff (PNS), two honorary teaching staff, one honorary gardener, one honorary office boy and two honorary teaching staff, and has 523 students. Employees at work need transformational leadership management so that Singkawang High School 3 can create maximum service to the community in these educational institutions.

\section{Methodology}

The research method used is descriptive research with a qualitative approach. The location of the study was conducted at Singkawang State High School 3. Data collected by in-depth interviews, participant observation, documentation, and analyzed through data reduction, data presentation, conclusions or verification. Data reliability testing is done by extending the observation period, and triangulation and member checking. The procedure in this study consisted of 3 stages:

\section{Pre-Research Stage}

Some activities were carried out before the researchers entered the field. Each of them is (1) compilation of the initial design of the study, (2) obtaining a research permit, (3) exploring the field and completing the research design, (4) selecting and interacting with subjects and informants, and (5) preparing assistive devices for activities field.

It should be noted, and researchers put interest and concern for the facts or symptoms of the principal's management to improve teacher performance and social consequences. A cursory observation was made long before the research design was prepared and submitted as a research topic. Armed with preliminary observations and literature review, the researcher submitted a research proposal on the management of school principals to improve teacher performance at Singkawang State High School 3. The proposed proposal is consulted with a supervisor and will be held in a seminar by inviting colleagues and experts. Because it uses a qualitative approach, this research proposal is seen as tentative. Therefore seminar opportunities are used to capture criticism and suggestions, both on topics and research methods. Based on these criticisms and input, the researcher revised the research design and conducted a field assessment.

Field assessment is carried out with three techniques simultaneously and flexibly, namely (1) observation; the researcher directly observes the management of planning carried out by the school principal and other elements in the Singkawang 3 High School environment, (2) interviews; researchers in-depth interviewed several informants, (3) document review; The researcher chooses and records relevant document data. Formulation of the problem and selection of more appropriate research methods are based on field assessment (grand tour observation). Throughout the fieldwork, of course, the focus of attention and techniques continued to experience sharpening and adjustment.

\section{Field Activity Stage}

In the implementation of this research, there were changes and improvements. Not only concerns the focus of research, but also on the research method. The concept of the sample in this study is related to selecting informants or specific social situations that can provide steady, correct, and trusted information about the elements of the research's focus. The selection of informants follows the snowball sampling pattern. If the introduction and social interaction with the informant were successful, then ask the person who else is known or indirectly mentioned by him. In determining the amount and time of interacting with data sources, researchers use the sampling concept recommended by Lincoln and Guba in Sugiyono (2009: 54), namely maximum variation sampling to document unique variations. Researchers will stop the data collection if no new physical 
body is found from the data source. With this concept, the number of data sources is not a primary concern, but rather the completeness of information acquisition with existing diversity. Not yet ascertained all the informants from the leadership provide the necessary data. Because the informant is a source of data that were interviewed in-depth. Each is four elements of leadership, three educators and one administrative staff. Because the primary data of this study were obtained based on interactions with informants in a natural setting, some equipment was prepared to make things easier, such as (1) stationery, (2) interview guidelines and android Samsung type A5 recording devices and photos using the Samsung Galaxy Tab android camera S, including field note sheet. This equipment is used if it does not interfere with the reasonableness of social interaction.

By interview, the researcher tries to obtain information by meeting face-to-face physically and answering questions with informants. With this technique, the researcher acts as well as a data collection tool. During the interview, the researcher will also examine the behavior of the informant in answering questions with researchers always trying to take advantage of opportunities and the most appropriate places to do interviews.

\section{Post-Field Stage}

After each field research activity has been completed, then all findings or data obtained are carried out triangulated, namely testing credibility as checking data from various sources, methods and times, including data processing, data reduction, data selection, grouping, and presenting data into patterns and consultations, determining themes, analyzing themes and completeness of data and consulting, testing the validity of data based on data and consultation groups, drafting reports and consulting designs, preparing research and consultation reports, test results (thesis examinations), thesis improvements and consultations, report submission.

\section{RESULTS AND DISCUSSION}

1. Planning a program to improve the quality of teacher performance

Based on the results of the analysis of research data on teacher performance planning at Singkawang State High School 3, some of the findings in this study are that schools already have a vision and mission that are compiled and socialized with school residents. The teacher quality improvement program is written in the school mission. The concept and purpose are based on the needs of schools to improve quality. There is an annual school work plan (RKS) prepared together with a team of teachers and a school committee. RKS is made for one school year and is based on the needs of eight national education standards (SNP). It is in accordance with research conducted by Wenno (2017), teacher performance is a key factor that should be taken into account in efforts to improve the quality of education. Several factors affect teacher performance. Principal Management is one of the factors affecting the success of teachers.
2. Implementation of quality improvement programs for teacher performance

Based on the results of the analysis of research data on the implementation of quality improvement programs for teachers' performance at Singkawang State High School 3, the positive tendency is the finding that there are already activities conduct ongoing professional development programs in the form of technical guidance (BIMTEK) learning development activities, In House Training (IHT) and workshops aimed at improving teacher competence and quality of learning.

3. Evaluate program activities to enhance the quality of teacher performance.

Teacher performance evaluation is done by conducting academic supervision activities on the teacher. Academic supervision activities are carried out on a scheduled basis by forming a supervision team involving the teacher council. In addition to academic supervision, managerial supervision of administration is also carried out.

\section{CONCLUSION AND SUGGESTION}

\section{A. Conclusions}

Based on the research findings and discussion of the results in the previous section, the teacher performance management at Singkawang 3 Public High Schools can be concluded as follows:

1. Planning for improving the quality of teacher performance at Singkawang State High School 3 is followed up with the preparation of a vision and mission and socialized with school members. The teacher quality improvement program is written in the school mission. The concept and purpose are based on the needs of schools to improve quality. There is an annual school work plan (RKS) prepared together with a team of teachers and a school committee. RKS is made for one school year and is based on the needs of eight national education standards (SNP).

2. The implementation of a program to improve the quality of teacher performance at Singkawang State High School 3 , a positive tendency is a finding that there are activities conduct ongoing professional development programs in the form of technical guidance (BIMTEK) learning development activities, In House Training (IHT) and workshops aimed at improving teacher competence and quality of learning.

3. Evaluation of teacher performance is carried out by conducting academic supervision activities on teachers. Academic supervision activities are carried out on a scheduled basis by forming a supervision team involving the teacher council. In addition to academic supervision, managerial supervision of administration is also carried out.

\section{B. Suggestion}

In accordance with the research findings, the problem results, and conclusions presented above, it is recommended to other researchers to be able to conduct further research 
related to improving the quality of teacher performance, not only on management standards but on other national education standards so that the existence of filial schools and their development is expected to be true can give a positive impact on the community, especially those who have obstacles in taking education.

\section{REFERENCES}

Danim, Sudarwan. (2009). Kepemimpinan pendidikan, kepemimpinan jenius, etika, perilaku motivasional dan mitos, Bandung: Alfabeta.

Mulyasa. (2013). Menjadi Kepala Sekolah Profesional. Bandung: PT Remaja Rosdakarya.

Peraturan Pemerintah Nomor 19 tahun 2005 tentang Standar Nasional Pendidikan.

Rahardjo, M. (2017). Desain penelitian studi kasus: Pengalaman empirik. UIN Malang.

Rusdiana (2016). Pengembangan Organisasi Lembaga Pendidikan. Bandung: Pustaka Setia.

Sugiyono. (2014). Memahami Penelitian Kualitatif. Bandung: Alfabeta.

Sulaksono, H. (2015). Budaya Organisasi dan Kinerja. Yogyakarta: Deepublish.

Supratikno, Hendrawan. (2006). Manajemen kinerja untuk menciptakan keunggulan bersaing. Yogyakarta: Graha ilmu, cetakan ke-1.

Wenno, I. H. (2017). Effect of Principal Managerial Leadership and Compensation towards Physics Teacher Performance in Senior High School in Baguala District-Ambon. International Education Studies, 10(1), 233-244.

Wibowo. (2011). Manajemen Kinerja. Jakarta: Raja Press.

Wiersma, W. (1986). Research Methods in Education: An Introduction. Massachusetts: Allyn and Bacon, Inc. 